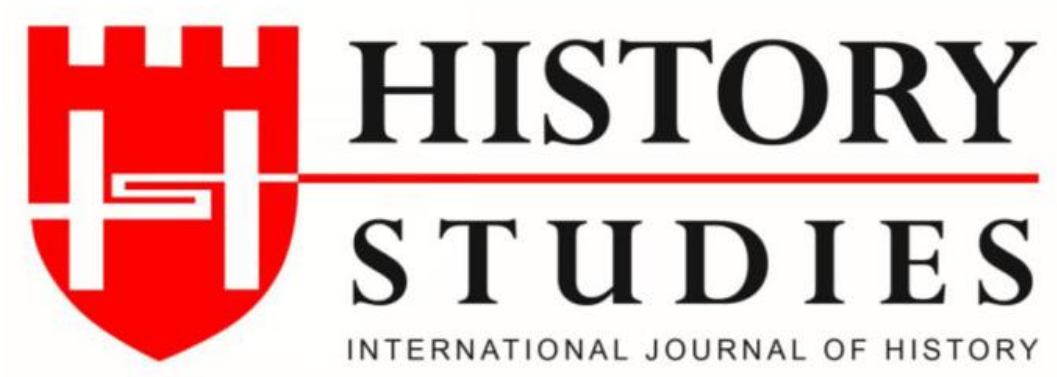

ISSN: 13094173 (Online) 1309 - 4688 (Print)

Volume 12 Issue 4, August 2020

DOI Number: 10.9737/hist.2020.890

Araştırma Makalesi

Makalenin Geliş Tarihi: 15.06.2020 Kabul Tarihi: 17.07.2020

Atıf Künyesi: Fatma Çapan, “VI. Asrın Başlangıcından Bulgarların Hristiyanlığı Kabul Etmesine Kadar Doğu Roma İmparatorluğu ile Bulgarlar Arasındaki Siyasi İlişkiler”, History Studies, 12/4,

Ağustos 2020, s. 1543-1560.

\title{
VI. Asrın Başlangıcından Bulgarların Hristiyanlığı Kabul Etmesine Kadar Doğu Roma İmparatorluğu ile Bulgarlar Arasındaki Siyasi İlişkiler
}

\section{Political Relations Between Eastern Roman Empire and Bulgarians From the Begining} of the Fourth Century to the Bulgarian Acceptance of Christianity

\author{
Dr. Fatma Çapan \\ ORCID No: 0000000286824179 \\ Gaziantep Üniversitesi
}

Volume 12

\begin{abstract}
Öz: Roma İmparatorluğu'nun sınırlarının oldukça genişlemesi üzerine merkezi otorite zayıflamıştır. Merkezi otoritenin yeniden güçlendirilmesi amacıyla başkent İstanbul'a taşınmış ve böylelikle Doğu Roma İmparatorluğu'nun temelleri atılmıştır. Doğu Roma İmparatorluğu bulunduğu coğrafyadan dolayı çeşitli kavimlerin saldırısına maruz kalmış ancak izlediği stratejiler sayesinde her saldırıdan en az zararla çıkmayı başarmıştır.
\end{abstract}

Balkanlar ve Tuna boylarına 630'lu yıllarda gelen Bulgarlar da kendilerine rakip gördükleri Doğu Roma İmparatorluğu topraklarına saldırmışlar ve çoğunlukla galip gelmişlerdir. Ancak bu saldırılar sırasında daha önceki kavimlere yaptığı gibi çeşitli diplomatik manevralarla ayakta kalmayı başaran Doğu Roma İmparatorluğu Bulgarlara karşı da bu siyaseti uygulamıştır. Güçlü olduğu zamanlarda Bulgarlara saldıran Doğu Roma İmparatorluğu güçsüz olduğunda veya başka bir cephede savaşmak zorunda kaldığında Bulgarlarla dost ve müttefik ilişkiler kurmuştur. Dolayısıyla bu politika Doğu Roma İmparatorluğu'nun ayakta kalmasını sağlarken rakiplerini ise güçsüz bırakarak bir müddet sonra yıkılmalarına neden olmuştur. Aynı durumu Bulgarlar da yaşamıştır. Bunun yanında Bulgar Devleti'ni kuran Türk nüfusunun azınlıkta olması, Slav unsurun çoğunluğu oluşturması diğer yandan az da olsa yaşanan taht kavgaları Bulgar Devleti'nin zayıflamasında etkili olmuştur. Elbette bu duruma Doğu Roma İmparatorluğu'nun köklü bir devlet olması da etki etmiştir.

Anahtar Kelimeler: Doğu Roma İmparatorluğu, Bulgarlar, Kubrat, Asparuh, Tervel, Omurtag.

Abstract: The central authority weakened upon the expansion of the borders of the Roman Empire. In order to reinforce the central authority, the capital was moved to Istanbul and the foundations of the Eastern Roman Empire were laid. The Eastern Roman Empire was attacked by various tribes due to its geography, but thanks to the strategies it followed, it managed to escape each attack with the least damage. 
Doğu Roma İmparatorluğu ile Bulgarlar Arasındaki Siyasi İlişkiler

Bulgarians, who came to the Balkans and Danube in the 630s, attacked the territories of the Eastern Roman Empire, which they saw as their rivals, and mostly prevailed. However, during these attacks, the Eastern Roman Empire, which was able to survive with various diplomatic maneuvers as it did before the tribes, started to implement this policy against the Bulgarians. The Eastern Roman Empire, which attacked the Bulgarians when it was powerful, established friendly and allied relations with the Bulgarians when they were weak or had to fight on another front. Therefore, this policy ensured the survival of the Eastern Roman Empire, leaving its rivals weak and causing them to collapse after a while. Bulgarians experienced the same situation. On the other hand, the fact that the Turkish population constituting the Bulgarian State was in the minority and the majority of the Slavic elements, on the other hand, the throne fights that were experienced in a small way, were effective in the weakening of the Bulgarian State. Of course, this was influenced by the fact that the Eastern Roman Empire was a rooted state.

Keywords: Eastern Roman Empire, Bulgarians, Kubrat, Asparuh, Tervel, Omurtag.

\section{Giriş}

Roma İmparatorluğu sınırlarının oldukça genişlemesi neticesinde doğudaki topraklarında merkezi otoriteyi kuvvetlendirmek amacıyla 330 yılında başkenti Konstantinopolis'e taşımışıtır. Başkentin taşınmasından sonra Hıristiyanlığın resmi din haline gelmesi, Grek kültüründen etkilenme gibi nedenlerden dolayı ise İmparatorluğun doğu yarısı batı yarısından farklı bir yönetim geleneğine ve kültüre sahip olmuştur. ${ }^{1}$ Doğu Roma İmparatorluğu ya da bazı batılı tarihçilerin bugün Bizans dediği İmparatorluk ortaya çıkmıştır. Ancak coğrafya nasıl insanların kaderlerini yönlendirmede etkiliyse devletlerin kaderini belirlemede de etkili bir unsur olduğu için Doğu Roma İmparatorluğu bu stratejik coğrafyada vücud bulmuş olmanın bedelini uzun asırlar boyunca ödemiştir. Nitekim öncelikle kendi içinde kadim düşmanı olan batı kavimlerinden Gotlar ile uğraşmak zorunda kalmıştır. Gotlara karşı verilen mücadeleler sırasında ise bazen onlarla savaş tercih edilirken bazen de onların savaşçıllk özelliklerinden yararlanılarak orduda ücretli askerler olarak görevlendirilmişlerdir. Ancak onların orduya bu şekilde girmeleri zamanla üst derecedeki rütbeleri ele geçirmelerine ve devlet siyasetinde kendi lehlerine belirleyici rol oynamalarına, çıkarları zedelendiği durumlarda da devlete karşı isyan etmelerine neden olmuştur. Doğuda Sasanilere karşı ise askeri bakımdan güçlü olduğunda savaşmayı tercih eden Doğu Roma, güçsüz olduğu zamanlarda onlara vergi vermeyi tercih etmiştir. Ancak bu vergi dönemlerinde hem ekonomik hem de askeri bakımdan güçlenen Sasaniler, Doğu Roma İmparatorluğu'nun en zayıf anlarını yakaladıklarında arkadan vurma konusunda asla tereddüt göstermemiştir. Bu konuda en bariz örneklerden birisi de Avarların İstanbul kuşatması girişimi sırasında Sasanilerin onlarla işbirliği yapmasıdır. İmparator Herakleios döneminde her ne kadar Sasani tehlikesi bertaraf edilse de doğudan gelen saldırıların arkası kesilmemiş bu kez de Müslüman-Arapların tehditleri baş göstermiştir. ${ }^{2}$

İmparatorluğa karşı bir başka tehdit ise Kuzeydoğu sınırlarından gelen ve asırlar boyu süren Kavimler Göçü ile harekete geçen Türk kavimlerinin saldırıları olmuştur. Karadeniz'in kuzeyinden batıya doğru yolculuklarına başlayan ve kendilerine yerleşmek için yeni yurtlar arayan Türk kavimleri ilk etapta Tuna'ya kadar ilerlemişlerdir. 370'li y1llardan itibaren başlayan Avrupa Hunlarının tehditleri Attila döneminde İmparatorluk için adeta bir kabusa dönüşmüştür. Doğu Roma, Avrupa Hunları'na yüklü miktarda vergi ve haraç vermek zorunda

\footnotetext{
${ }^{1}$ Alexander A.Vasiliev, Bizans Imparatorluğu Tarihi, (Türkçeye Çev.,Tevabil Alkaç), Alfa Tarih Yay., İstanbul, 2016, s.74-77;Georg Ostrogorsky, Bizans Devleti Tarihi, (Türkçeye Çev., Fikret Işıltan), TTK Yay., Ankara, 1999, s.40-43.

${ }^{2}$ Daha geniş bilgi için bkz. Ostrogorsky, agt, s.86-104.
} 
kalmıştır. Attila'nın ani ölümü üzerine Doğu Roma İmparatorluğu bir süre rahat nefes alabilmiştir. Daha sonra Attila'nın oğulları İrnek ve Dengizek arasındaki anlaşmazlıklar nedeniyle Avrupa Hun Devleti bir daha Attila dönemindeki gücüne kavuşamamış ve devlet dağılmıştır. ${ }^{3}$

Avrupa Hunlarının tehlikesinin atlatılmış olması Doğu Roma'yı kuzeydoğudan gelen bu tehlikelerden kurtulduğu anlamına gelmemiştir. Çünkü kısa bir süre sonra Avarlar aynı coğrafyada imparatorluğu tehdit etmeye başlamıştır. Avarlar İstanbul'u iki defa kuşatmışlar ve ikisinde de başarısız olmuşlardır. Nitekim daha sonraki süreçte ise Avarlar diğer topluluklar arasında kaybolmuşlardır.

Doğu Roma İmparatorluğu Avarlardan sonra bu kez aynı coğrafyada Bulgar Türklerinin tehdidi ile karşı karşıya gelmiştir. ${ }^{4}$ Dolayısıyla diğer Türk kavimleri ile olduğu gibi siyasi koşullara göre Bulgarlar ile de zaman zaman dostça münasebetlere girilerek askeri ittifaklar yapılırken zaman zaman da doğrudan çetin savaşlar yapılmıştır. Ancak Doğu Roma İmparatorluğu'nun Bulgar Türkleri üzerine uyguladığı Hıristiyanlaştırma politikası başarıya ulaşmış ve bundan sonraki süreçte Bulgar-Bizans ilişkilerine dini politikalar da yön vermeye başlamıştır.

\section{Bulgarların Ortaya Çıkışı ve Doğu Roma İle İlk Münasebetler}

Attila'nın ölümünden sonra oğulları arasında çıkan anlaşmazlıklar nedeniyle siyasi birlik sağlanamamış ve bu kardeşlerden Dengizik, Doğu Roma ile yaptığı savaşlar sırasında ölmüştür. Attila'nın en küçük oğlu İnek ise başarısızlıkla sonuçlanan mücadelelerden sonra bu coğrafyada tutunmanın mümkün olmadığını anlayınca kendisini destekleyen Hun kabileleri ile birlikte Karadeniz'in kuzey-batı sahillerinde yaşamını sürdüren soydaşlarından Ogur $^{5}$ Tükleriyle birleşerek tarihte Bulgar diye bilinen Türk devletinin temellerini atmıştır. ${ }^{6}$

Ogur Türkleri Volga(İtil)'dan Tuna ağzına kadar büyük bir sahada yayılmış ve federasyonlar halinde yaşamaktaydılar. Bunlardan Oturgur(Utigur-Utrigur=30 Ogur) adıyla bir Ogur grubu Kafkasya'da, On-Ogurlar Don ile Kuban nehirleri arasinda, Kutrigur(9 Ogur)'lar Don ile Dinyeper arasında yaşamaktaydı. Ayrıca Bittugur (5 Ogur), Ultingur(6 Ogur)'lar, Saragur(Sarı-ak Ogur)'lar ve Kara-Ogurlar olarak adlandırılan ve aynı coğrafyanın çeşitli sahalarında yaşayan gruplar da bulunmaktaydı. ${ }^{7}$ Ogurlar her ne kadar idari bakımdan ayrı

\footnotetext{
${ }^{3}$ Attila dönemi Hun-Bizans İlişkileri hakkında daha geniş bilgi için bkz. Fatma Çapan, Balkanlar'da Bizans-Türk Ilişskileri(IV.-X. Yüzyıllar), Yayınlanmamış Doktara Tezi, Elazığ, 2013, s.36-72.

${ }^{4}$ Ostrogorsky, age, s. 156.

5 “Ogur Türkleri Çin kaynaklarına göre M.Ö III. Yüzyılın sonlarında Asya Hun Devleti’nin batı kanadını oluşturan bir Türk kolu olup, Doğu Avrupa'ya göçleri sonucunda Bulgarların teşekkülünde önemli bir rol oynamışlardır. Daha geniş bilgi için bkz. İbrahim Kafesoğlu, Bulgarların Kökeni, Türk Kültürünü Araştırma Enstitüsü, Ankara, 1985, s.4-7;Hüseyin Namık Orkun, Attila ve Oğulları, Remzi Kitaphanesi Yay., İstanbul,1933, s.132-147;W. Eberhard, Çinin Şimal Komşularl, Ankara 1942, s.70; İbrahim Kafesoğlu,Türk Milli Kültürrü, Boğaziçi Yay., İstanbul, 1993, s.79; Ali Ahmetbeyoğlu, Avrupa Hun Imparatorluğu, TTK Yay. Ankara, 2001, s.124-125.

${ }^{6}$ Nitekim Bulgar Türklerine ait olan "Hakanlar Listesi"”nde İrnek ilk sırada yer almaktadır. Bkz. Ali Ahmetbeyoğlu, "Bulgar Hakanlar Listesi", Tarih Enstitüsü Dergisi, İstanbul Üniversitesi Edebiyat Fakültesi Dergisi(Ayrı Basım), İstanbul 1994, s.2-3;Osman Karatay, “Omurtak Han'ın Rüyası”, Türk Dünyast Tarih Dergisi, S.183, Mart 2002, s.41; Akdes Nimet Kurat, "Tuna Bulgarları", İslam Ansiklopedisi, C.II, Milli Eğitim Basımevi Yay., İstanbul, 1961, s.796.

${ }^{7}$ Ali Ahmetbeyoğlu, Grek Seyyahı Priskos(V.Asır)'a Göre Avrupa Hunları, Türk Dünyası Araştırmaları Vakfi, İstanbul, 1995, s.65-66;Kafesoğlu, age,s.6-7; Şerif Baştav, "Sabir Türkleri”, Belleten, S.1718,1941,s.53;Orkun, age, s.147-150.
} 
olsalar da siyasi bakımdan özellikle dışarıdan herhangi bir tehdit hissedildiğinde birlikte hareket ediyorlardı. Ogurların batıdaki kollarından olan Dokuz Ogurlar, siyasi temaslar kurarak vergiye bağladıkları Doğu Roma ile bazen dostça bazen de düşmanca ilişkiler içinde olmuşlardır. Nitekim Doğu Roma İmparatoru Justinianos zamanında bunların tehlikesinden korunmak için Tuna boyuna 80 kadar kale yaptırılmıștır ${ }^{8}$. Bunun yanı sıra Doğu Roma İmparatorluğu yine bir düşmanını diğerine karşı kışkırtma oyununa başvurarak 552-553 yıllarında bu boyları birbirine karşı kışkırtıp savaşa tutuşturmayı başarmıştır. ${ }^{9}$ Nihayetinde 558 yılında Doğu Roma ile Avarlar arasında yapılan anlaşma gereğince Avarlar, Sabirler, Onogurlar ve diğer kavimlere saldırmışlar ve bu sırada birbirleriyle mücadele halinde olan Kutrigur ve Utigurlara da hücum ederek onları hakimiyetleri altına almışlardır. ${ }^{10}$

626 yılında Avarların İstanbul kuşatmasında başarısız olmaları onların siyasi saygınlığını yitirmesine neden olmuş ve merkezi otoriteleri sarsılmaya başlamıştır. 630 yılında ise Avar hanının ölümü üzerine çıkan taht kavgaları nedeniyle bir iç savaş patlak verince Avarlara bağlı olan Bulgarlar da taht iddiasıyla isyan etmişlerdir. Nitekim 630 yılında dayısı veya amcası Organa'nın yerine Bulgarların başına geçen Kubrat Han ${ }^{11}$, Avarları mağlup edip onları Karadeniz'in kuzeyine göç ettirmeyi başarmıştır. ${ }^{12} \mathrm{Bu}$ sırada Göktürklerin Çin hakimiyetine girmesini firsat bilen Kubrat Han hem Avar hakimiyetinden çıkan Bulgarlar ile hem de I. Göktürk Devleti'nin yıkılması sonucu serbest kalan Azak civarındaki Onoguri ve Otuzgur, gibi Ogur boylarını birleştirerek 635 yılında Büyük Bulgar devletini kurmuştur. Böylece Bulgar adını taşıyan ilk devlet ortaya çıkmıştır. ${ }^{13}$

Kubrat Han Büyük Bulgar Devleti'ni kurduktan sonra Doğu Roma İmparatoru Herakleios'a(610-641) elçi göndermiştir. İmparator Herakleios, Avarların Sasaniler ile imparatorluğa karşı yaptığı ittifaka karşı yeni bir müttefik olarak değerlendirdiği Büyük Bulgar Devleti'nin elçilerini kabul ederek Kubrat Han'a hediyeler göndermiş ona patrik ünvanı

\footnotetext{
${ }^{8}$ Roma İmparatorluğu Karadeniz'in jeopolitik konumunu kendisi için avantaja çevirmek nedeniyle hem güçlü bir askeri yapı oluşturmuş hem de Avrupa eyaletleri ile Ren ve Tuna nehirlerini doğal bir set olarak görmüş ve buraların savunmasına önem vermiştir. Bkz. Zeynel Özlü-Kerim Tiryaki, "Tarihi Süreçte Karadeniz’in Jeopolitik Önemi(BULGAR SAVA N.IVANOF'A GÖRE)”, İlkçağlardan Günümüze Jeostratejik ve Jeopolitik Açıdan KARADENIZ, Akçă̆ Yayınları, Ankara 2018, s.18.

${ }^{9}$ Kafesoğlu, age, s.8-9.

${ }^{10}$ Orkun, age, s.153-154; M.İ.Artamanov, Hazar Tarihi(Türkler, Yahudiler,Ruslar), (Çev.,Ahsen Batur), Selenge Yay., İstanbul-2004, s.148;Kafesoğlu, Bulgarların...,s.9;Kurat, s.796.

${ }^{11}$ Kubrat Han'ın Bulgar Türklerinin Avar hakimiyetinden çıkıp müstakil yaşama hareketleri başladı̆̆ dönemde hangi görevde bulunduğu bilinmemektedir. Ancak bu siralarda bir Hun-Ogur(Hun-Bulgar) beyi olan dayısı veya amcası Organa(Origin)'nın yanında yetiştiği tahmin edilmektedir. Kubrat Han hakkında daha geniş bilgi için bkz. Rasonyı, Tuna Köprüleri, Türk Kültürünü Araştırma Enstitüsü Yay., Ankara, 1984, s.16;P.B Golden,, Türk Halkları Tarihine Giriş, (Çev. Osman Karatay), Karam Yay. Çorum-2006, s.287-288; Geza Feher, Bulgar Türkleri Tarihi, Ankara, 1985, s.30-31;Kafesoğlu, Bulgarların... s.1213;Kafesoğlu, Türk Milli... s.191-192; Ali Ahmetbeyoğlu, “Kubrat Han ve Büyük Bulgar Devleti'nin Kuruluşu”, Karadeniz Araştırmalart Dergisi, S.13(Bahar 2007), s.35-37;Ali Ahmetbeyoğlu, "Bulgar Hakanlar Listesi”, Tarih Entitüsü Dergisi, İstanbul Üniversitesi Edebiyat Fakültesi Dergisi(Ayrı Basım), İstanbul,1994, s.1-8;Talat Tekin, Tuna Bulgarlart ve Dilleri, Ankara 1987, s.3.

12 İbrahim Kafesoğlu, “XII. Asra Kadar İstanbul'un Türkler Tarafından Muhasaraları”, İstanbul Enstitüsü Dergisi, C.III., İstanbul, 1957, s.10-11.

${ }^{13}$ Çapan, agt,s.147-148; Kurat, agm,s.796; Kafesoğlu, Bulgarların..., s.11; Feher, age, s.31, Ahmetbeyoğlu, Kubrat Han...s.37-38; Rasony1, age,s.16; Osman Karatay, "Tuna Bulgar Devletinin İlk Asrı:Balkanlarda Tutunma ve Pekişme(681-803)", Türk Dünyası Íncelemeleri Dergisi, S.X/2, Kış 2010, s.2; Şerif Baştav, "Hazar Kağanlığı Tarihi”, Makaleler 1, Berikan Yay., Ankara-2005, s.435-436.
} 
vermiştir. ${ }^{14} \mathrm{Bu}$ anlaşma Kubrat Han'ın kurduğu devletin siyasi varlığını resmi olarak dönemin en güçlü imparatorluğuna tasdik ettirmesi açısından büyük önem taşımaktadır. Dolayısıyla Kubrat Han, bu anlaşmaya ömrü boyunca sadık kalmış ve Herakleios'un ölümünden sonra bile çıkan taht kavgalarında Herakleios'un eşi Martini ve oğlunu desteklemiştir. Kubrat Han'ın ölümünden sonra oğulları arasında çıkan kavgalar ve Hazarların baskıları nedeniyle Büyük Bulgar Devleti varlığını uzun süre devam ettirememiş ve devlet dağılmıştır. ${ }^{15}$

\section{Asparuh Han Dönemi(640-702)'nde Doğu Roma İmparatorluğu İle İlişkiler}

Kubrat Han'ın ölümünden sonra oğlu Asparuh, Dinyeper ile Dinyester'i geçerek Tuna'nın denize dökülen kısmına yerleşmiştir. Asparuh önderliğindeki Bulgarlar Tuna yakınlarına geldiği sıralarda Doğu Roma İmparatorluğu doğu sınırlarında Müslüman Araplara karşı büyük yenilgiler alarak Suriye, Filistin, Mısır gibi önemli topraklarını kaybetmişlerdi. Diğer yandan 626 yılında İstanbul kuşatmasından sonra zayıflamış olsalar da Avarlar varlıklarını sürdürüyorlardı. $\mathrm{Bu}$ nedenle Doğu Roma İmparatorluğu Balkanlardan gelecek herhangi bir tehlikeye karşı kendini savunacak durumda değildi. ${ }^{16} \mathrm{Bu}$ durumu firsata çevirmeyi bilen Asparuh 679 yılında bölgede dağınık bir halde yaşayan Slavları da hakimiyet altına alarak 300 yıl varlığını sürdürecek olan Tuna Bulgar Devleti'ni kurmuştur. ${ }^{17}$ Ancak bir Türk devleti olarak ortaya çıkmasına rağmen hakimiyeti altındaki yerleşik Slav kültürü ve Hıristiyanlıktan etkilenerek zaman içerisinde oldukça büyük bir değişime uğramıştır. Özellikle Slavların Balkan yarımadasına Bulgarlardan yaklaşık bir buçuk asır önce yerleşmesi ve onların nüfus bakımından daha yoğun olması nedeniyle esasen Bulgarların teşkilatlandırdığı Slavlar, Bulgar Devleti'nin nüfus bakımından hakim unsuru haline gelmiş ve zamanla Tuna Bulgarları kalabalık Slav nüfusu tarafından asimile edilmiştir. Ancak bahsi geçen bu karışma devletin kurulduğu ilk yüzyılda değil, IX. ve X. yüzyıllarda gerçekleşmiştir. ${ }^{18}$

Volume 12

Bulgarlar bu tarihlerden sonra Doğu Roma İmparatorluğu siyasi ve askeri tarihinde oldukça önemli rol oynamıştır. Başlangıç itibariyle Doğu Roma ile dostane ilişkiler kuran ${ }^{19}$

\footnotetext{
${ }^{14}$ Burada Heraklius tarafindan Kubrat Han'a Patrik ünvanının verilmesi ise İmparator Heraklius'un Kubrat Han ile ilişkilerine ne derecede önem verdiğini göstermektedir. Bkz. Ostrogorsky, age, s.97.

${ }^{15}$ Nikephoros Patriarch of Constantınople, Shorty History,(Trans, Cyrıl Mango), Dumbarton Oaks Research Library and Collection, Washington, 1990 s.89;The Chronicle of Theophanes(A.D.,602-813), (Edited and Translated by Harry Turtledove), University of Pennslvania Press, Philadelphia, 1982, s.498;Art;Z. Miftakov, "İlk Bulgar Devlet Oluşumları", Türkler Ansiklopedisi, C.II, s.623;İ. Kafesoğlu, Türk Milli...s.190-191;Golden s.288-289; Feher, age,s.31-32; Kurat, agm, s.782;Çapan, agt, s.150153;Sezgin Güçlüay, "Bulgar Hanları Krum ve Omurtag Dönemlerinde Bizans İmparatorluğu'nun Balkan Politikası", Tarih ve Siyaset Bilimi Araştırmaları, Akademisyen Kitapevi Yay., Ankara,2019, s.60-61.

${ }^{16}$ Ahmetbeyoğlu, "Yurt Tutan Hükümdar Asparuh ve Tuna Bulgar Devleti'nin Kuruluşu”, Omeljan Pritsak Armağanı,(Yay. Haz. M. Alpargu, Y. Öztürk), Sakarya,2007, s.396-397;Kurat, agm, s.797.

${ }^{17}$ Bkz. Rasony1, age,s.23-26;Çapan, agt, s.153-155; Kurat, agm, s.782.

${ }^{18}$ Bkz. Vasiliev, age,s.277-278; Golden, s.290;Karatay, "Tuna Bulgar Devletinin İlk Asr1...,s.6; Ahmetbeyoğlu, "Yurt Tutan Hükümdar Asparuh...", s.400-401.

${ }^{19}$ Doğu Roma kaynaklarının Bulgar Devleti’nin ilk 75 yılından yeteri kadar bahsetmeyişine bakılırsa bu tarihlerde başka bir yerde meşgul olan Doğu Roma'nın Bulgarlara müdahale edemediği tahmin edilebilir. Nitekim Arkeolojik bulgular Asparuh'un bu sükûnet dönemi içerisinde devleti teşkilatlandırmak için çalıştığını göstermiştir. Bu dönemde Bulgarlar sınır bölgelerinin tahkimi ve alınan yerlerin güvenliği için Slavları Doğu Roma ve Avar devletleri sınırlarına yerleştirdiler ve zayıf bölgelere sınır istihkamları inşa ettiler. Böylece bu korunaklı sınırların içinde Bulgarlar ve Slavlar kaynaşarak bir millet oluştu. Bulgar Türklerinin sayesinde bu milletin maddi ve manevi durumu günden güne gelişti. Nitekim Bulgarların sınırlarını bu şekilde sıkı bir şekilde koruma altına almasının nedeni ise Doğu Roma'nın imkan bulduğu anda saldırıya geçme ihtimalidir. Bkz.Feher, s.48.
} 
Asparuh(640-701) önderliğindeki Bulgarlar, hem Hazarlardan kaçmak hem de yeni yerleşim alanları bulmak amacıyla, Tuna deltasının kuzeyindeki topraklardan Dobruca'nın güneyindeki Doğu Roma topraklarına saldırılar düzenlemeye başlamışlardır ${ }^{20}$. Doğu Roma İmparatoru IV. Konstantinos(668-685) ise o sırada Arapların İstanbul'u kuşatması nedeniyle onlara karş1 koyacak güçte olmadığında Kuzey Dobruca'ya yerleşmelerine izin vermiştir. ${ }^{21}$

Arapların İstanbul kuşatmasında başarısız olup geri çekilmesinden sonra rahatlayan Doğu Roma İmparatoru IV. Konstantinos(668-685) 679 yılında büyük bir deniz ve kara kuvveti ile bu kez Bulgarlara karşı harekete geçmiştir. ${ }^{22}$ Donanmayı Tuna deltasına gönderen imparatorun kendisi de topladığı kara ordusuyla birlikte Oglos bölgesi üzerinden Bulgarlara karşı harekete geçmiştir. Dobruca'yı korumak amacıyla Çernova ile Köstence arasındaki istihkamları harekete geçiren Asparuh ise IV. Konstantinos'un ordusunu durdurmak amaciyla Beserabya'daki müstahkem mevkilerine çekildi. Böylece Doğu Roma ordusu Tuna bataklıkları arasında hareketsiz kaldı. Bu durum karşısında morali bozulan ordu, İmparatorun hastalık nedeniyle İstanbul'a dönmesi üzerine Mesembria'ya çekildi. Daha sonra Doğu Roma ordularını izleyen Bulgarlar Tuna'yı geçerek Varna'ya girdiler. Böylece Doğu Roma'nın Bulgarlar'ı bertaraf etmek için yaptığı bu sefer aksine onların ilerlemelerini kolaylaştırmıştır. ${ }^{23}$ Bulgarların bu başarısı sonucunda akın yaptıkları arazide yaşayan kalabalık Slav kitleleri Bulgarlara vergi vermeyi kabul ederek Doğu Roma'ya karşı onlarla birleştiler. ${ }^{24}$ Bulgarların gittikçe güçlenmesine engel olamayan Doğu Roma İmparatoru IV. Konstantinos ise 681 yılında Asparuh ile barış imzalamak zorunda kalarak, vergi vermeyi dahi kabul etmiştir. Bunun yanı sıra Bulgarlara Tuna ile Balkanlar arasındaki havalileri yani eski Mezya ve Skitya(bugün kü Dobruca) vilayetlerini de vermeyi kabul etmiştir. Böylece Bulgar Devleti'nin sınırları Karadeniz'den İsker ırmağına, güneyde Balkan dağlarına kadar uzanmıştır. ${ }^{25}$ Diğger yandan bu anlaşmayla Doğu Roma İmparatorluğu, kendi toprakları üzerinde kurulan bu siyasi teşekkülü resmen tanımış ve Bulgarlar Balkanlar'da ve Orta Avrupa'da önemli bir rol oynamaya başlamıştır. Hatta Bulgarlar zaman zaman, zayıflayan Doğu Roma İmparatorluğu'nu kuzeyden gelebilecek kavimlere karşı korumuşlardır. ${ }^{26}$ Doğu Roma'nın doğudan ve kuzeyden gelen akınları durduramaması ve Balkanlar'daki huzurun bozulmasına rağmen Bulgar Türk Devleti'nin bulunduğu bölgede devamlılık olması bu rolün önemini arttırmıştır. ${ }^{27}$

IV. Konstantinos'un ölümünden sonra yerine oğlu II. Justinianos(685-695;705-711) geçti. II. Justinianos, babası ile Asparuh arasında yapılan anlaşmayı bozmuştur. ${ }^{28}$ Doğu Roma için tehdit oluşturan Bulgarlara daha fazla haraç ödemek istemediği için 688-689 yıllarında

\footnotetext{
${ }^{20}$ Vasiliev, age, s. 277.

21 Acaroğlu, Bulgaristan Türkleri Üzerine Araştırmalar I, Kültür Sanat Yay., İstanbul, 2007, s.32;Ahmetbeyoğlu, "Yurt Tutan Hükümdar Asparuh...", s.396-397;Çapan, agt, s.156;Kurat, agm, s.797.

${ }^{22}$ G.Moravcsik, Byzantınoturcica, I, Budapeşte, 1942, s.51.

${ }^{23}$ Ali Ahmetbeyoğlu, "Yurt Tutan Hükümdar Asparuh...", s.399.

${ }^{24}$ Karatay, "Tuna Bulgar Devletinin İlk Asr1...,s.7-8;Rasony1, age, s.23;Artamonov, age, s.232;Acaroğlu, Bulgaristan Türkleri Üzerine...s.32;İbrahim Kafesoğlu, "Türk-Bulgar'ların ve Kültürüne Kısa Bir Bakış”, Güneydoğu Avrupa Araştırmaları Dergisi, S.10-11, İstanbul Üniversitesi Edebiyat Fak. Basımevi, İstanbul, 1983, s.102.

25 Theophanes, age, s.57;Nikephoros, age,s.91;Kafesoğlu, “Türk Bulgar'lar...”, s.102;Acaroğlu, Bulgaristan Türkleri Üzerine...s.32;Nikolay Todorov, Bulgaristan Tarihi, Çev: Veysel Ataman, Öncü Kitapevi Yay., İstanbul-1979, s.15;Çapan, agt.,s.157.

26 Vasiliev, age,s.277;Ahmetbeyoğlu, "Yurt Tutan Hükümdar Asparuh...", s.400; Ostrogorsky, age, s.117-118.

${ }^{27}$ Feher, age, s.46.

${ }^{28}$ Ostrogorsky, age, s. 120-121.
} 
Bulgarlar üzerine yürümüştür. Justinianos'un niyetini anlayan Bulgarlar, Trakya'ya doğru ilerlemişler ancak İmparator onları geri püskürterek batıya doğru yönelmiş ve Selanik'e ulaşmıştır. ${ }^{29}$ Ancak bu sefer dönüşünde İmparator'un yolu, ordusu ile birlikte Bulgarlar tarafından Güney Rodop geçitlerinde kesilmiştir. İmparator kuvvetlerinin büyük bir bölümünü kaybederken kendisi de güçlükle kurtulabilmiştir. ${ }^{30}$

\section{Tervel Han Dönemi(702-718) ve Doğu Roma İmparatorluğu İle İlişkiler}

Asparuh Han'ın ölümü üzerine yerine oğlu Tervel Han(702-718) geçiştir. ${ }^{31}$ Onun döneminin en önemli olayı Doğu Roma'nın taht kavgalarına Bulgarların müdahalesi olmuştur. $^{32}$ İmparator II. Justinianus Doğu Roma İmparatorluğu tahtında bulunduğu birinci dönemde uyguladığı politikalar nedeniyle gözden düşmüş, dili ve burnu kesilerek Khersones'e(Kırım) sürgüne gönderilmiştir. ${ }^{33}$ Ancak II. Justinianus tahtı tekrar ele geçirmek için çeşitli planlar yapmıştır. Ancak Kırım'da bulunduğu sırada Kırım halkının kendisini öldürme planlarından haberdar olunca Hazarların elindeki Doros kentine kaçmayı başarmıştır. Burada bir süre kalan II. Justinianus, Hazar kağanına mektup yazarak ondan yardım istemiştir. Onun bu isteği Hazar Kağanı tarafindan olumlu karşılanmış ve karşı bir mektup ile onurlandırıldığı gibi Hazar Kağanı kendi kız kardeşi olan Hazar Hatununu da II. Justinianus'a eş olarak göndermiştir. Diğer yandan tahttan indirilen hükümdarın faaliyetleri ve Hazar Kağanı ile olan münasebetleri İstanbul'da dikkatle takip edilmekteydi. O esnada Doğu Roma İmparatorluğu tahtında bulunan II. Tiberios bir elçisini Hazar Kağanı'na yollayarak II Justinianus'un teslimi halinde pek çok hediyenin verileceğini bildirince Hazar Kağan'1 II. Justinianus'u imparatora teslim etmeye karar vermiştir. ${ }^{34}$ Fakat II. Justinianus'un eşi bu gelişmeleri Hazar Kağanı'nın yanında bulunan hizmetçilerinden birinden öğrenmiş ve II. Justinianus'u bu konuda bilgilendirmiştir. Bunun üzerine II. Justinianos oradan kaçmayı başararak Bulgar hükümdarı Tervel'in yanına sığınmıştır. ${ }^{35}$

Issue 4

August

II. Justinianus Tervel Han'a tahtı ele geçirmesinde yardım ederse pek çok hediye ve öz kızını Tervel'e eş olarak vereceğini söylemiştir. II. Justinianos'un bu isteğine olumlu cevap veren Tervel Han, ordusuyla birlikte İstanbul'a yürümüştür. Bu ordu karşısında yenilgiye uğrayan İmparator II. Tiberios'un kaçması üzerine başkente girmiş ve II. Justinianos'un ikinci kez tahta çıkmasını sağlamıştır(705). ${ }^{36}$ II. Justinianos, Tervel Han'a yaptığ 1 bu yardım karşılığında, IV. Konstantinos(668-685) zamanında Bulgarlara ödenen vergiyi de tekrar vermeyi kabul etmiştir. Ayrıca Tervel Han'a şükran ifadesi olarak önemli hediyelerle birlikte Caesar ünvanı verilmiştir. Bu unvan İmparatordan sonra Doğu Roma'nın en yüksek şeref

\footnotetext{
${ }^{29}$ Ostrogorsky, age, s.121-122;Feher, age, s.48.

${ }^{30}$ Nikephoros, age, s.93;The Chronicle of Theophanes, age,s.70-71; Feher, age, s.48.Karatay, agm,s.7.

${ }^{31}$ Ahmetbeyoğlu, "Tervel Han(702-718)", Prof.Dr. Bekir Kütükoğlu’na Armă̆an, İstanbul-1991, s.564.

${ }^{32}$ Acaroğlu, "Bulgar Türkleri Üzerine...", s.32;Çapan, agt ., s.160;Kurat, agm, 797.

${ }^{33}$ II. Justinianos'un sert bir şekilde aristokrasi düşmanlığı yapması, zor kullanmaktan çekinmemesi ve halkını zorla tehcir ve iskan siyasetine tabi tutması, insanları yurtlarından zorla çıkarıp, bilmedikleri ve alışamadıkları bölgelere atması halkının da düşmanlığına neden olmuştur. Diğer yandan kendine örnek aldığı I. Justinianus gibi mimari hayata fazlasıyla önem vermesi, halkı VII. yüzyılın sonlarına doğru büyük bir vergi yükünün altında bırakmıştı. Bu durum Maviler Partisi’nin II. Justinianus idaresini sona erdirme planlarına taraftar bulmuştur. Maviler Partisi'nin huzursuz halk kitlesini arkasına almasıyla II. Justinianus tahttan indirilmiştir. Daha geniş bilgi için bkz. Theophanes, age, s.67;Ostrogorsky, age, s.130131.

34 Theophanes, age, s.70.

${ }^{35}$ Theophanes, age, s.71; Ostrogorsky, age, s.132.

${ }^{36}$ Theophanes, age,s.71;Çapan, agt., s.162-163; Kurat, agm, 797.
} 
ünvanıydı ve ilk defa yabancı bir hükümdara veriliyordu. Caesar ünvanının alınması Tervel Han için ayrıca bir önem arz etmekteydi. Çünkü böylece Doğu Roma bir kez daha Bulgar Devleti'nin varlığını resmen onaylamış oluyordu. Ayrıca Haemus(Balkan) sıradağlarının güneyindeki şimdiki Zağra(Zagora) olarak bilinen bölge de Bulgarlara bırakılmıştır. Böylece Tervel Han, Doğu Roma'daki siyasi karmaşayı firsata çevirerek yönetim üzerinde tahakküm kurmayı başarmıştır. Diğer yandan bu gelişmeler sayesinde Bulgar Devleti dış politikada gücünü hissettirmeye ve topraklarını genişletmeye başlamıştır. ${ }^{37}$

II. Justinianos ikinci kez tahta çıktıktan sonra üç yıl boyunca kendisine muhalif olanları bertaraf etmekle uğraşmıştır. Ülkesinde tam anlamıyla hakimiyet sağladıktan sonra, Tervel Han'ın Doğu Roma üzerindeki nüfuzunu kırmak için Bulgarlar üzerine yürümeye karar vermiştir. ${ }^{38}$ Tervel Han'ın daha çok miktarda vergi talep etmesini de bahane eden II. Justinianos, ordusunu donanmanın yanaştığı ve oldukça güvenli bir nokta olan Karadeniz kıyısındaki Anchialios'a yerleştirmiştir. Ancak II. Justinianos burada Bulgarlar tarafından bir baskına uğramış ve bir gece gemiyle kaçarak canını zor kurtarmıştır(708). ${ }^{39}$ Bundan sonraki süreçte uyguladığı intikam politikalarından dolayı oldukça düşmanı olan İmparator II. Justinianos 711 yılında Ermeni Philippikos'un isyanı sonucunda hem tahtını hem de hayatını kaybetmiştir. Ostrogorsky ve Vasiliev'in aktardığına göre Bulgarlar Philippikos döneminde II. Justinianos'a yapılanların intikamı amacıyla ya da haraç ödenmemesiyle ilgili olarak İstanbul'a bir baskın yaparak, şehrin etrafında dolaşmış ve buldukları her şeyi yağmalamışlardır. Ancak hiçbir mukavemet görmeden geri dönmüşlerdir. Trakya tarafındaki zayıflı̆̆ takviye için Marmara'nın güneyinden İstanbul'a aktarılan kuvvetler ise isyan ederek imparatoru tahttan indirmiştir(713). ${ }^{40}$ Dolayısıyla Doğu Roma İmparatorluğu'ndaki taht kavgalarında Bulgarların tutumu her durumda belirleyici olmuş, Doğu Roma tahtına kalıcı bir imparator gelmeyince de savaş durumu sürekli olmuştur. 713'te Doğu Roma tahtına çıkan II. Anastasius(713-715) da iki y1l tahtta kalabilmiş ve yerine III. Theodosios(715-717) ${ }^{41}$ geçmiştir.

716 yılında Doğu Roma İmparatoru III. Theodosios ile Tervel Han arasında Bulgar Devleti ile Doğu Roma sınırını belirleyen bir barış anlaşması yapılmıştır. Buna göre iki devlet arasında, Kuzey Trakya'dan yani Burgaz körfezinden başlayarak Edirne-Filibe yolunun Meriç Nehri ile kesiştiği hat sınır kabul edilmiştir. Böylece Bulgar Krallı̆̆ı, güney sınırı bakımından Trakya Ovası'na doğru genişlemiştir. Ayrıca bu anlaşma ile Doğu Roma İmparatorluğu yıllardır aksayan y1llık vergiyi ödemeyi kabul etmiş ve iki devlet siyasi mültecileri birbirine teslim etmeyi de kararlaştırmıştır. Ayrıca İki ülke tüccarlarının serbest ticaret yapmaları, bu tüccarların pasaport taşımaları, sattıkları malların damgalı olması, aksi takdirde bu mallara el

\footnotetext{
${ }^{37}$ Nikolay Todorov Tervel Han'ın o gün kü siyasi konjoktürde ne kadar güçlü olduğunu ifade eden durumu Suidas ansiklopedisinden şu şekilde aktarmıştır: "Bulgaristan'ın hükümdarı Tervel, İmparator Justinyan zamanında mutluluğun zirvesine erişti. Justinyan'ın kendisi ve Heraklios'un oğlu Konstantin, Tervel'e haraç vermek zorunda kalmıştır. Savaş zamanlarında taşıdığı kalkanını ters çevirdi;kısrağında kullandığı kırbacını da yanına koydu. Sonra kalkanla kırbaç görünmez oluncaya kadar üstlerine para yığdı. Mızrağını yere uzattı ve bir ucundan diğer ucuna üstünü ipek elbiselerden oluşan bir tepecikle örttü. Keseleri altın ve gümüş sikkelerle doldurdu, sağ eliyle altını, sol eliyle gümüşü askerlerine dağıttı". Bkz. Todorov, age, s.16;Nikephoros, age, s.105;Theophanes,age,s.525;Ostrogorsky, age,s.133;Golden, age, s.291;Ahmetbeyoğlu, "Tervel Han...”, s.564-565;Çapan, agt., s.162.

${ }^{38}$ Theophanes, s.73; Ali Ahmetbeyoğlu, "Tervel Han...", s.565-566;Feher, age, s.49.

${ }^{39}$ Nikephoros, age, s.105;Theophanes, age, s.525; Ahmetbeyoğlu, “Tervel Han...”, s.566.

${ }^{40}$ Ostrogorsky, age, s.143;Vasiliev, age, s.289-290.

${ }^{41}$ Ostrogorsky, age, s. 144-145.
} 
konulmasına karar verilmiştir. Böylece Tervel Han, ülkesinin sınırlarını emniyet altına alırken, devletinin ekonomik kalkınmasını ve dünya ticaretine katılmasını temin etmeyi başarmıştır. ${ }^{42}$

717 yılında Doğu Roma İmparatorluğu tahtına Ermeni asıllı III. Leon'un(717-741) tahta çıkmasıyla beraber taht kavgaları sona ermiş ve imparatorluk istikrarlı bir döneme girmiştir. ${ }^{43}$ Tervel Han ise başlangıçta III. Leon aleyhine devrik II. Anastasius'u desteklemiş ancak Anastasios buna rağmen başarılı olamayınca onu yeni imparatora teslim ederek Doğu Roma ile barış anlaşması yapmak zorunda kalmıştır. ${ }^{44}$ Bundan sonraki süreçte Bulgarlar 717-718 yıllarında İstanbul'u kuşatan Araplara karşı Doğu Roma'nın yanında yer almıştır. Araplara karş1 20.000 kişilik ordu ile Doğu Roma'ya destek veren Tervel Han Arapların yenilgiye uğramasını ve geri çekilmelerini sağlamıştır. Dolayısıyla bu barış anlaşması Doğu Roma'nın güçlü bir askeri müttefike sahip olmasını da sağlamıştır. ${ }^{45}$ Tervel Han'ın 718 yılından sonraki faaliyetleri ile ilgili herhangi bir bilgi bulunmadığından dolayı bu olay onun son faaliyeti olarak kabul edilmektedir. ${ }^{46}$ Tervel Han 16 yıllık hakimiyet süresi boyunca Doğu Roma üzerinde güçlü bir tahakküm kurmuş, zaman zaman taht kavgalarına doğrudan müdahele ederek zaman zaman da Doğu Roma'ya askeri bir müttefik olarak nüfuzunu iyice kuvvetlendirmiştir. Nitekim arkasında da Tuna'dan Trakya'ya kadar uzanan güçlü bir devlet bırakmıştır. ${ }^{47}$

\section{Tervel Han'dan Sonra 718-802 Yılları Arası Doğu Roma İmparatorluğu İle İlişkiler}

Tervel Han'dan sonraki dönemde Bulgar tahtına sırasıyla Tvirem(718-724) ${ }^{48}$, Sever Han(724-739), Kormış Han(739-756) geçmiştir. ${ }^{49}$ Bunlardan Tvirem ve Sever Han dönemlerinde Doğu Roma İmparatorluğu'nun başında Leon gibi güçlü ve askeri firsatları kaçırmayan bir imparator bulunuyordu. Dolayısıyla Bulgar cephesinde de durumun iyi olmasından kaynaklanan bir barış dönemi yaşandığı tahmin edilmektedir. Bu dönemle ilgili Doğu Roma kaynaklarının sessizliği de bu şekilde açıklanabilir. Kormisoş/Kormış'ın ${ }^{50}$ son zamanlarında anlaşmazlıkların başlamasıyla Tuna Bulgarlarından tekrar Doğu Roma kaynaklarında bahsedilmeye başlanmıştır. ${ }^{51}$

V. Konstantinos(741-775) tahta çıktığı sırada devletin doğusunda Emevi Devleti y1kılıp yerine Abbasi Devleti kurulmuştur. Bu süreç içerisinde İslam dünyası içerisindeki siyasi boşluklardan yararlanan Doğu Roma, Araplar karşısında savunma konumundan taarruz

42 Kurat, agm,797; V.N Zlatarski, “Krum Han”, Çev:M.Türker Acaroğlu, Güney Doğu Avrupa Araştırmaları Dergisi, S.10-11, İstanbul Üniversitesi Edebiyat Fak. Basımevi, İstanbul 1983,s.240247;Çapan, agt.,s.164; Feher, age, s.49; Ayşe Kayapınar, "Tuna Bulgar Devleti(679-1018)", Türkler Ansiklopedisi, C.II, Yeni Türkiye Yay., Ankara-2002, s.632.

${ }^{43}$ Ostrogorsky, age, s.145;A. Vasiliev, age,s.290.

${ }^{44}$ Nikephoros, age, s. 127.

${ }^{45}$ Kurat, agm, 797;Golden, age, s.291; Feher, age, s.49;Kafesoğlu, “Türk Bulgar'lar...”, s. 103.

${ }^{46}$ Feher, age, s.50-51.

${ }^{47}$ Ali Ahmetbeyoğlu, “Tervel Han...”,s.568;Çapan, agt., s.165.

${ }^{48} \mathrm{Bu}$ kelime Bulgar Türkçesinde 'dokuzuncu' (tokuz-tokur-tovır-tıvir+em) demektir. Bkz. Tekin, age,s.23.

${ }^{49}$ Kurat, agm,797;Zlatarski, agm, s.256-257;Bazı yazarlar, Tervel Han'dan sonraki Bulgar Han'ının ismini unutulmuş olarak kabul ettikleri için Tervel Han'dan sonra doğrudan Sever Han'ın ismini zikretmektedirler. Dolayısıyla Sever Han dönemini de 718-754 y1lları aras1 ya da 736-740 yılları aras1 olarak kabul etmektedirler. Ancak Tervel Han döneminden sonra isimsiz olarak zikredilen bu Han'ın ismi Tvirem olarak tespit edilmiştir. Bu nedenle Sever Han dönemi 724-739 yılları arasıdır. Bkz. Feher, age,s.50;Kayapınar, agm, s.632;Çapan, agt, s.167; Güçlüay, agm,s.63-64.

50 "koru" kökünden Korumuş olması mümkündür. Bkz. Karatay, s.11.

${ }^{51}$ Karatay, agm,s.11;Çapan,ag., s.167. 
konumuna geçmiştir. ${ }^{52}$ Ancak Arap saldırılarının zayıflamasıyla birlikte Bulgarlar ile Doğu Roma arasında yeniden savaşlar dönemi başlamıştır. Dolayısıyla zor durumda olduğunda Bulgarlardan faydalanarak onlarla askeri ittifak yapan Doğu Roma İmparatorluğu, işi bittiğinde Bulgar Devleti'ni yıkmak için her yola başvurmuştur. ${ }^{53}$ V. Konstantinos'un(741-775) Bulgar sinırında kaleler inşa ettirmesi ve buralara Suriyeli ve Ermeni göçmenleri askeri sınıf olarak yerleştirmeye başlaması Doğu Roma ile Bulgarlar arasındaki barış dönemi sona erdiğinin bir göstergesidir. ${ }^{54} \mathrm{Bu}$ durum karşısında Bulgarlar inşa edilen kaleler için haraç talep etmişler aksi takdirde ise 716 yılında kendilerine ihdas edilen vergi miktarının arttırılmasını istemişlerdir. $\mathrm{Bu}$ sebeple Bulgarlar, Doğu Roma'ya elçiler gönderseler de olumsuz cevap almışlardır. Bu gelişmeler üzerine 755 yılında Trakya'ya giren Bulgarlar Doğu Roma ordularına karşı yenilgiye uğrayarak geri çekilmek zorunda kalmışlardır. ${ }^{55}$ İmparator V.Konstantinos bundan sonra Bulgar Devleti'ni tamamen ortadan kaldırmak amaciyla Bulgarlar üzerine tam dokuz sefer düzenlemiştir. Ancak bu seferler hedefine ulaşamamıştır. Bunun yanı sıra İmparator Konstantinos bazı yazarlar tarafından Bulgarlara karşı yapmış olduğu bu savaşlardan dolayı "İlk Bulgar öldürücüsü"(Bulgaroktonus) olarak adlandırılmıştır. ${ }^{56}$

756 yılında Doğu Roma karşısında tutunamayan Kormış Han Bulgar Boyar'ları tarafından öldürülerek yenilgisinin cezasını hayatı ile ödemiştir. ${ }^{57}$ Yerine oğlu Vineh(756-761) geçtiyse de bu dönem iç karışıklıklar ve taht kavgalarıyla geçmiştir. Vineh 759 yılında Doğu Roma İmparatorluğu ile bir barış yapmış ancak İmparator anlaşmayı yeniden ihlal ederek Bulgarlar üzerine yürümüştür. Fakat bu kez muvaffak olamayan İmparator geri çekilmek zorunda kalmıştır. ${ }^{58}$ Diğer yandan bu yıllarda Bulgar Devleti içerisinde iç huzursuzluklar baş göstermiş 761 yılında ülkenin gidişatından rahatsız olan Bulgar beyleri Vineh Han'a karşı ittifak yaparak onu öldürmüş ve Telets'i (761-764) tahta çıkarmıştır. Telets tahta çıkar çıkmaz Doğu Roma İmparatorluğu topraklarına akınlara başlamıştır. ${ }^{59}$ Ancak 763 yılında harekete geçen Doğu Roma İmparatoru V. Konstantinos Bulgarlarla kanlı bir meydan savaşı yaparak onları yenilgiye uğratmıştır. Bu durum Telets'e karşı bir isyan çıkmasına ve onun öldürülmesine neden olurken devlet içerisinde de y1llarca sürecek iç karışıklıkların başlamasına neden olmuştur. Devlet yönetimine bazen Doğu Roma yanlısı bazen Doğu Roma karşıtı kişiler gelmiş ve Doğu Roma İmparatorluğu ise bu durumu firsat bilerek Bulgar Devleti'nin iç işlerine karışmış ve kendi aleyhinde durumlar geliştiğinde de Bulgarlara karşı savaş açmıştır. ${ }^{60}$

765-767 yılları arasında Bulgar tahtına çıkan Sevin döneminde Doğu Roma ile iyi geçinme adına barış arayışı içine girilmiştir. Ancak onun barış arayışları Bulgar beyleri arasında hoş karşılanmamış ve isyan çıkmıştır. Bunun üzerine Sevin Han kaçarak Doğu Roma'ya sığınmıştır. Daha sonra tahta Theophanes'e göre Bayan Han, Nikephoros'a göre Pagan Han adlı biri geçmiştir. ${ }^{61} \mathrm{Bu}$ Bulgar Hanı da barıştan yana tavır sergilemiş ve Doğu Roma ile barış

\footnotetext{
${ }^{52}$ Ostrogorsky, age, s. 155-156.

${ }^{53}$ Feher, age, s.50; Vasiliev, age, s.303.

${ }^{54}$ Golden, age, s.292;Feher, age, s.50;Vasiliev, age, s.303;Ostrogorsky, age, s.156. barış istediler". Bkz. Nikephoros, age,s.145.

${ }^{56}$ Vasiliev, age,s.303.Ostrogorsky, age, s.156-157;Çapan, agt., s.168-169.

${ }^{57}$ Kafesoğlu, "Türk-Bulgar'lar...", s.103.

${ }^{58}$ Feher, age, s.50.

${ }^{59}$ Güçlüay, agm,s.64;Zlatarski, agm,s.282

${ }^{60}$ Ostrogorsky, age,s.156-157;Karatay, agm,s.13;Çapan, agt., s. 170.

${ }^{61}$ Nikephoros, age, s.149-151;Theophanes, age,s.125;Feher, age, s.51.
}

${ }^{55}$ Feher, age,s.50;Vasiliev, s.303;Kayapınar,s.633; Ostrogorsky, s.156. Nikephoros bu bilgiye kısaca şunu ekler: "İmparator onları yendi ve kanlı bir takiple kovaladı. Ardından da karadan ve denizden bir karşı sefere çıktı. Gemiler Tuna'dan girdiler ve Bulgarlara büyük zarar verdiler. Çaresiz kalan Bulgarlar 
yapmıştır. Ancak bu barış zamanında geçitlerin korumasız olduğunu fark eden imparator ani bir kararla Bulgaristan'a saldırarak Tuna boylarına kadar ilerlemiştir. ${ }^{62}$ İmparatorun donanmasını gören Bulgarlar, barış istemişler ancak bu sırada çok büyük bir firtına Doğu Roma donanmasını neredeyse yok etmiştir. ${ }^{63}$

Doğu Roma orduları çekildikten bir yıl sonra Bulgar tahtına Telerig Han(768-777) çıkmıştır. Onun tahta çıkmasıyla Bulgar Devleti kendisini toparlayarak yeniden eski savaş gücüne kavuşmuştur. Telerig döneminde de V. Konstantinos, 773 yılında büyük bir ordu ve donanmayla yeniden Bulgaristan'a sefer düzenlemiş ve Bulgarları barış görüşmeleri için zorlamıştır. Ancak Bulgarlar ile Doğu Roma arasında kalıcı bir barış sağlanamamıştır. İmparator İstanbul'a döndüğünde Bulgarların Makedonya'daki bir Slav kabilesini alıp Doğu Roma topraklarına yerleştirmek üzere ordu gönderdikleri haberini almıştır. Bunun üzerine İmparator bir plan yaparak Araplar üzerine bir sefer düzenleme havası yaratarak ani bir şekilde Bulgarlara saldırmıştır. Böylece Bulgarlara karşı kendisi büyük bir kayıp vermeden zafer kazanmıştır. ${ }^{64} \mathrm{~V}$. Konstantinos 775 yılında Bulgarlara karşı yeniden bir sefer düzenlese de bu sefer sırasında ateşli bir hastalığa yakalanarak ölmüştür. ${ }^{65}$ Böylece Bulgar Devleti önemli bir tehlikeden kurtulmuştur.

Doğu Roma İmparatorluğu tahtına IV. Leon'un(775-780) çıkmasıyla birlikte Bulgarlara karşı daha yumuşak bir politika izlenmiştir. ${ }^{66} \mathrm{Bu}$ arada ülkesinde Doğu Roma'ya karşı savaş ve kesin zafer isteyen beyleri memnun edemeyen Telerig Han iç çekişmeler nedeniyle IV. Leon'un yanına sığınmak zorunda kalmış ve Hıristiyanlığı kabul ederek 777 yılında bir Doğu Roma prensesi ile evlenmiştir. ${ }^{67}$ Telerig Han'dan sonra tahta çıkan Kardam Han(777-802) döneminde merkezi otorite güçlenmiş, Balkan Slavları üzerinde Bulgar egemenliği daha da yayılmış ve içteki taht mücadeleleri sona ermiştir. ${ }^{68}$ VI. Konstantinos(780-802) tarafından 789 yılında başlatılan Bulgar sınırındaki savaşlar da başarısızlıkla sonuçlanmıştır. 791 ve 792 yıllarında Doğu Roma, Bulgarlara karşı taarruz teşebbüsünde bulunduysa da Kardam Han onlanı yenilgiye uğratmış, İmparator savaş meydanından kaçarken, Doğu Roma kumandanlarının bir çoğu esir düşmüştür. ${ }^{69}$ Bulgarların bu şekilde güçlenmesi üzerine Doğu Roma İmparatoru VI. Konstantinos Bulgarlara y1llık vergi ödemeyi kabul etmiştir. Böylece Bulgar Devleti iç politikada olduğu gibi dış politikada da rahat bir nefes almıştır. ${ }^{70}$

Kardam Han, Bulgar Devleti'nin gücünü iyice arttırmak için Doğu Roma İmparatorluğu'nun durumunu yakından takip etmiştir. Doğu Roma ile açık meydan savaş1 yapmaktan kaçınan Kardam Han daha çok savunma stratejisi izlemiş ve merkezi otoriteyi güçlendirmeye çalışmıştır. ${ }^{71}$

\section{Krum Han Dönemi(802-814)'nde Doğu Roma İmparatorluğu İle İlişkiler}

Kardam Han'dan sonra Bulgar tahtına oğlu Krum Han(802-814) geçmiştir. Bundan sonraki yarım yüzyıl Bulgar Devleti’nin en parlak dönemi olmuştur. ${ }^{72}$ İçeride devlet otoritesini

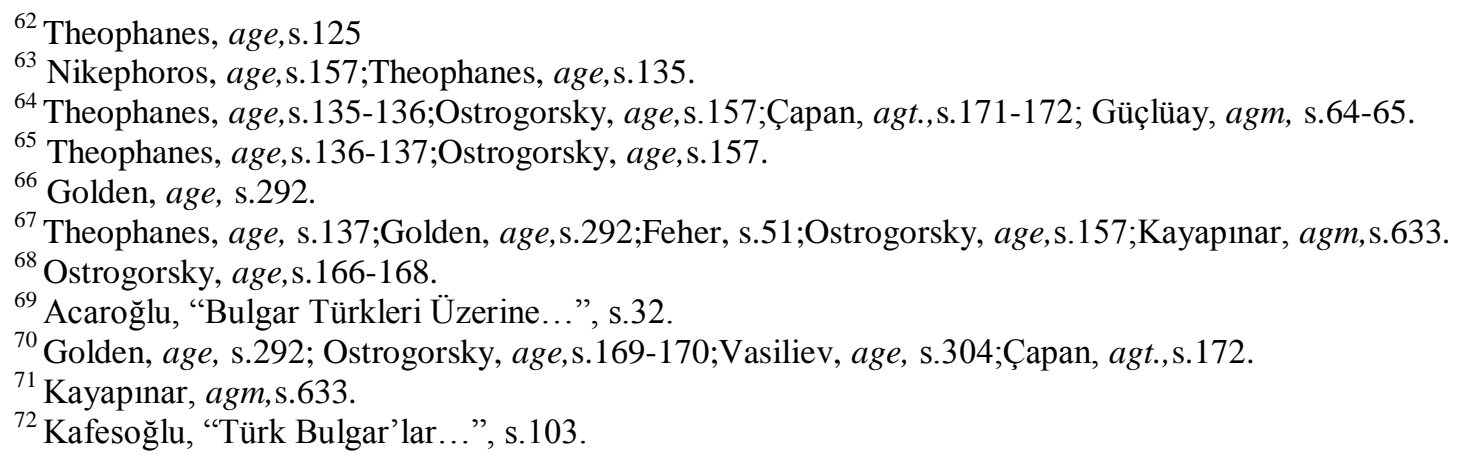


güçlendiren Krum Han kendisinden önceki hükümdarların izlediği savunma politikasının yerine saldırı politikası izlemeye başlamış ve Doğu Roma İmparatorluğu'nun en tehlikeli düşmanı haline gelmiştir. ${ }^{73}$

802 yılında Doğu Roma tahtına çıkan I. Nikephoros(802-811) Doğu'da Arap tehlikesinin atlatılmasından sonra Bulgar Devleti'ne karşı düşmanca politikalar izlemeye başlamıştır. $\mathrm{O}$ sırada İmparatorun uyguladığı mali politikalardan rahatsız olan Peleponez Slavları isyan etmiş ancak bu isyan İmparatorluk tarafından zor kullanılarak bastırılmıştır. Peloponez Slavlarının başına gelenleri gören Makedonya Slavları ise, Bulgarlardan yardım istemiştir. Bunu firsat bilen Bulgarlar bu çağriya olumlu cevap verince bu ittifaktan hoşlanmayan İmparator 807 yılında Bulgarlar üzerine bir sefer düzenlemiştir. Ancak Edirne'de ordusunda çıkan ayaklanma nedeniyle bu seferden vazgeçen İmparator Nikephoros başarıya ulaşamamıştır. ${ }^{74}$

808 yılında Krum Han, Struma Irmağı bölgesinde aniden bir saldırı düzenleyip Doğu Roma ordularını yenilgiye uğratmış ve askerlere maaş olarak ayrılan altınları ele geçirmiştir. ${ }^{75} 809$ yılında yeniden harekete geçen Krum Han kısa zamanda Doğu Roma'nın Bulgarlara karşı set olarak kullandığı, Edirne, Sofya, Niş gibi önemli ticaret merkezlerini ele geçirmiştir. Böylece Bulgar toprakları Doğu-Batı ticaretinde önemli bir transit merkezi ve konaklama merkezi haline gelmiştir. Nikephoros 809 yllında Bulgarların bu yönde ilerleyişini engelleyebilmek amacıyla Balkanlar'daki Slav bölgelerine Anadolu'dan Doğu Roma-Hıristiyan göçmenlerinin yerleştirilmelerini emretmiştir. İmparatorun bir başka amacı Slavlar arasında Bulgar etkisine engel olmak onların Bulgarlar ile birleşmesini önlemek olmuştur. ${ }^{76}$ İmparator Nikephoros'un aldığı bu önlemler Bulgarların büyük başarılarını ve İmparatorluk için ne kadar büyük bir tehdit oluşturduklarının önemli bir göstergesidir. ${ }^{77}$

Doğu Roma İmparatorluğu'nun elinde bulunan önemli ticaret merkezlerini alan Krum Han'ın en önemli hedeflerinden biri de İstanbul'u ele geçirmekti. Bunu anlayan İmparator Nikephoros ülkesini savunmak için bir takım tedbirler aldıysa da başarılı olamamıştır. Özellikle Anadolu'dan binlerce ailenin evlerinden, yurtlarından koparılarak zorla Balkan sinır bölgelerine yerleştirilmesi bütün imparatorlukta hoşnutsuzluk yaratmış ve bu durum savunma kuvvetini arttıracağı yerde zayıflatmıştır. Ayrıca imparatorun bu insanlara para ve malzeme vermemesi, Bulgarlara karşı savaşa çıkarken halka ve kiliselere yeni vergiler yüklemesi onu başarısızlığa götüren nedenlerden olmuştur. ${ }^{78}$

İmparator Nikephoros 811 yılında Bulgarlar üzerine harekete geçtiğinde Krum Han'ın barış teklifine aldırmadan Bulgar Devleti'nin başkenti Pliska'yı tahrip ederek hanın sarayını yaktırmıştır. Bunun üzerine Krum Han askerlerine, Balkan Dağları'nda Vırbitsa geçidini tutmalarını emrederek 26 Temmuz 811'de ordusu ile birlikte geri dönen Nikephoros'a saldırmış ve bu savaşta Doğu Roma ordusu Krum Han tarafından kuşatılarak imha edilirken İmparator Nikephoros da savaş meydanında öldürülmüştür. ${ }^{79}$ Krum Han Nikephoros'un başını kestirerek zaferinin simgesi olarak eski Türk geleneğine göre kafatasından kadeh yaptırmıştır. Böylece Bulgarlar üzerindeki Doğu Roma üstünlüğü sona ererken Makedonya Slavlarının

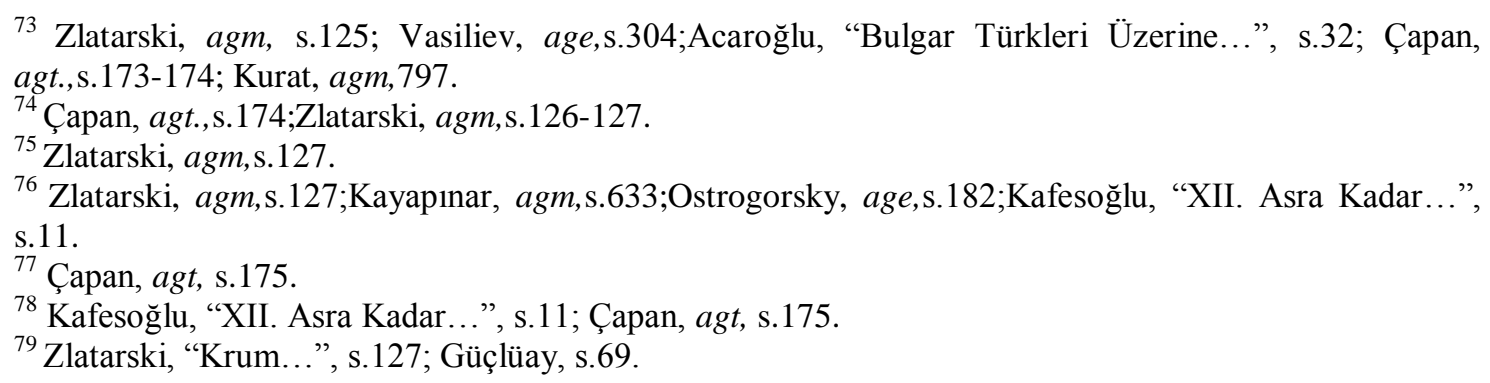


gözünde Bulgarların itibarı artmış ve devletin güney batıya doğru genişlemesi için bir yol açılmıştır. ${ }^{80}$ Ostrogorsky bu zaferin sonuçlarını şöyle değerlendirmiştir: “...Bu beklenmez felaketin sonuçları pek büyük oldu. Bizans itibarının yediği darbe belki de uğranılan askeri çöküntüden de ağırdı. Kavimler göçü devrinden, 378 yılında İmparator Valens'in Vizigotlara karşı yapılan Edirne savaşında maktul düşmesinden beri hiçbir Bizans hükümdarı barbarlar tarafından katledilmemişti. Üstünlüğünü savaşın ilk safhasının yeteri kadar açık olarak belirttiği Bizans yerlere serilmiş yatarken, kısa süre önce barış için yalvarmış bulunan Krum şanlı, şöhretli bir zafer kahramanı olmuştu. Kendisine emniyeti ölçüsüz derecede artmış ve fütühat arzularına hayâl edilmesi bile güç bir ufuk açılmıştı...".

Nikephoros'un ölümü üzerine yerine Mihail Rangabe (811-813) geçmiştir. ${ }^{82}$ İmparator Mihail 812 Haziran ayı ortalarında Bulgarlara karşı bir intikam seferine çıktıysa da ordudaki disiplinsizlikler nedeniyle geri dönmek zorunda kalmıştır. Bunun üzerine daha da cesaretlenen Krum Han, Doğu Roma başkenti İstanbul'u ele geçirmek için harekete geçmiştir. Öncelikle Filibe ve civarını alan Krum Han, Mesembria kalesini kuşattıktan sonra İstanbul'a anlaşma yapmak üzere bir elçi göndererek 716 yılında yapılan anlaşmayı yenilemek ve yeni maddeler eklemek istemiştir. Krum Han Bulgarlardan Doğu Roma'ya kaçanların iadesini, Grek tüccarların belli başlı pazarlarda ticaret yapmasını ancak her tüccarın elindeki malların cinsini ve miktarını Bulgar makamlarına bildirmelerini ve yıllık vergi talep etmiştir. Ancak Krum Han'ın bu teklifi Doğu Roma İmparatorluğu tarafından reddedilmiştir. Doğu Roma İmparatoru bu teklifi reddettiği 2 Ekim 812 günü stratejik konumu, zenginliği ve Trakya'nın zahire deposu haline getirilmiş olan Mesembria'nın düştüğünü öğrenmiştir. Bulgarlar kalede oldukça fazla miktarda altın, gümüş ve diğer ganimetlerden başka Grejuva Rum ateşi için kullanılan 36 tunç tüp ele geçirmişlerdir. ${ }^{83}$ Bundan sonra Doğu Roma İmparatorluğu devlet adamları arasında Bulgarlar ile barış veya savaş konusunda bir anlaşmazlık söz konusu olmuştur. Başlarında Patrik Nikephoros'un bulunduğu grup İmparatorun da görüşüne uygun olarak barıştan yana tavır sergilerken Studios manastırı başrahibi Theodoros'un başını çektiği grup savaş yanlısı tutum izlemiş ve başrahibin görüşü galip gelmiştir. ${ }^{84}$

Doğu Roma İmparatoru Mihail Rangabe, 813 yılı Haziran ayında büyük bir ordu hazırlayarak yola çıkmıştır. Zaten ilerlemekte olan Krum Han kuvvetleri ile Edirne yakınlarındaki Versinikia'da karşılaşmıştır. Her iki ordu uzun bir süre saldırı konusunda kararsız bir tutum izlemiş ancak yanında bulunan Kapadokya ve Ermeni kıtaları kumandanı Ermeni Leon'un tahrikleri sonucunda Temmuz ayının sıcak günlerinde Doğu Roma orduları Bulgarlara saldırmıştır. Nitekim, bir günlük çarpışma sonucunda Doğu Roma orduları Bulgarlar tarafından yenilgiye uğratılmış ve Leon kuvvetleri geri çekilmek zorunda kalmıştır. Bunun üzerine I.Mihail tahtan indirilerek yerine Ermeni Leon getirilmiştir. ${ }^{85}$

Kazandığı bu zaferden daha fazla şeyler isteyen Krum Han kardeşi Kışın'1 Edirne muhasarasında bırakarak, İstanbul surları önünde görünmüştür. ${ }^{86}$ Krum Han birkaç taarruzdan

\footnotetext{
${ }^{80}$ Ostrogorsky, age,s.182-183; Kurat, agm,797;Feher, age, s.53; Kafesoğlu, “XII. Asra Kadar...”, s.12; Zlatarski, agm,s.129-130;Todorov, age, s.16; Çapan, agt., s.175-176.

${ }^{81}$ Ostrogorsky, age, s.183.

${ }^{82}$ Ostrogorsky, age, s.184; Vasiliev, age, s.315.

${ }^{83}$ Zlatarski, agm, s.130-131;Ostrogorsky, age,s.186-187; Çapan, agt., s.176.

${ }^{84}$ Ostrogorsky, age, s. 187.

${ }^{85}$ Ostrogorsky, age, s.187;Vasiliev, age, s.326; Kafesoğlu, XII. Asra Kadar...s.12-13; Çapan, agt., s.177.

${ }^{86}$ Kafesoğlu, “Türk-Bulgar'lar...", s.105.
} 
sonra İmparator Leon'a y1llık vergi ve elbiselik kumaş karşılığında anlaşma teklif etmiştir. ${ }^{87}$ Barış şartlarını görüşmek üzere her iki taraftan beşer kişinin surlara oldukça yakın bir yerde toplanması ve heyette bulunanların yanında silah bulundurmaması kararlaştırılmıştır. Ancak Leon bu şartlara uymamış ve adamlarına Krum'u öldürmelerini emretmiştir. Görüşme sırasında Krum Han bu suikast girişimini birden bire fark ederek süratli atı sayesinde kurtulabilmiştir. ${ }^{88}$ Leon'un bu ihaneti üzerine Bulgar ordusu şehrin etrafındaki bütün binaları tahrip ederek esirleri öldürmüştür. Edirne'ye giren Krum Han burayı aldıktan sonra Edirne ve Trakya sakinleri arasından yaklaşık 10.000 kişiyi esir almıştır. Bunları Tuna'nın kuzeyindeki Bulgaristan'a yani bugünkü Oltana ve Montana'ya iskân etmiş̧ir. Böylece devletin kuzeydoğu sınırları düşman akınlarına karşı bu asker göçmenler sayesinde koruma altına alınmıştır. $\mathrm{O}$ devirde İmparatorluğun hem nüfus bakımından hem de yüzölçümü açısından İmparatorluğun ikinci büyük şehri olan Edirne'nin Bulgarların eline geçmesi Doğu Roma için önemli bir kayıp olmuştur. $^{89}$

813 yllında İstanbul'u ele geçirmek için yeniden harekete geçen Krum Han büyük bir hazırlığa başlamıştır. Bulgar askerlerinin yanı sıra Slavlar ve Avarların da katıldığı büyük bir ordu hazırlamıştır. Arcadiopolis'i(Lüleburgaz) zaptettikten sonra İstanbul surları önüne gelmiştir. Bu durum karşısında İmparator Leon, halk ve senatörler artık İstanbul'un kurtuluşu için büyük mucize beklemeye başlamıştır. Krum Han bu sırada Doğu Roma'ya barış teklifinde bulunduysa da bu reddedilerek savaş yolu seçilmiştir. Nitekim yapılan savaşta Doğu Roma ordusu Bulgarlara karşı yenilmiştir. Ertesi yıl 814 y1lı Nisan ayında Krum Han'ın aniden ağzından ve burnundan kan boşalmasıyla ölümü nedeniyle bu girişimi yarıda kalmış ve Doğu Roma rahat bir nefes almıştır. ${ }^{90^{3}}$

\section{Omurtag(814-831) ve Oğlu Malamir(831-836) Dönemi Doğu Roma İmparatorluğu İle İlişkiler}

Krum Han'dan sonra Bulgar tahtına oğlu Omurtag(814-831) geçmiştir.91 Omurtag'ın hükümdarlık döneminde devletin yönü kuzey batıya yöneldiği için Doğu Roma ile Bulgarlar arasında otuz yıllık bir barış antlaşması yapılmış ve bir süre sukunet sağlanmıştır. Böylece Bulgar Devleti'nin içinde bulunduğu maddi güçsüzlük ve manevi yorgunluğu gidermek bakımından gerçekçi bir siyaset izlenmiştir. ${ }^{92} \mathrm{Bu}$ anlaşmanın şartları Süleymanköy(Bugün kü Şumnu iline bağl1 Secişte Köyü) civarında bulunan kitabede geçmektedir. ${ }^{93} \mathrm{Bu}$ anlaşma ile Karadeniz kıyısındaki Develtos'dan başlayarak Mesemvriya'ya kadar olan yerler Doğu Roma'ya terk edilirken, güneybatı yönünde Meriç nehrine, oradan da Rodopların kuzeyinden geçerek Filibe ovasına ulaşan ve Sofya bölgesini de içeren yerler Bulgarlara bırakılmıştır. Anlaşmayla Bulgar Devleti güney sınırlarında huzura ve sükûnete kavuşmuş, Doğu Roma İmparatorluğu da ticaret mallarını gümrük vergisi ödemek şartıyla kuzey yönünde sevk

\footnotetext{
${ }^{87}$ V. Leon'un resmen İmparator ilan edilmesi ve donanma olmadan İstanbul'u kuşatmanın sonuç vermeyeceğinin Krum Han tarafinda anlaşılması nedeniyle Doğu Roma İmparatorluğu'na barış teklifinde bulunulması ihtimali yüksektir. Bkz. Zlatarski, agm, s.133.

${ }^{88}$ Zlatarski, agm, s.134-135.

${ }^{89}$ Kafesoğlu, "XII. Asra Kadar...", s.13; Zlatarski, agm, s.135-137Rasony1, age, s.25.

${ }^{90}$ Ostrogorsky, age, s.186-188;Vasiliev, age,s.326; Kurat, agm,797;Golden, age, s.293; Kafesoğlu, "XII. Asra Kadar...", s.13-14;Vasiliev, age, s.352-353;Zlatarski, agm, s.138-139;G.Moravcsik, Byzantinoturcica, I, s.51; Çapan, agt, s.178.

91 Türkçe'de Omurtag, kartalcık anlamına gelmektedir. Moravcsik, Byzantinoturcica, II,s.217-218; Tekin, age, s.53-54; Rasony1, age, s.26;Kafesoğlu, “Türk-Bulgar'lar...”, s.106.

92 Ostrogorsky, age, s.188;Vasiliev, s.326; Kurat, agm,797;Golden, s.295;Kafesoğlu, "TürkBulgar'lar...", s.107.

93 Kayapınar, agm, s.634.
} 
edebilme imkânına kavuşmuştur. Ayrıca bu anlaşma ile Krum Han tarafından da Bulgar topraklarına nakledilen Hıristiyan unsurların geri gönderilmesi taahhüt edilmiştir. Bu anlaşmayla Doğu Roma ikinci kez Bulgarların toprak kazançlarını resmen tanımıştır. ${ }^{94}$ Anlaşma daha sonra Doğu Roma İmparatoru II. Mihail(820-829) döneminde yenilenmiştir. Bundan sonra Doğu Roma ile Bulgarlar arasındaki ilişkiler barış içinde devam etmiştir. Hatta Bulgar Hanı müttefik olarak 823 y1lında Doğu Roma İmparatorluğu'nda meydana gelen Thomas isyanının bastırılmasında İmparatora yardımcı olmuştur. ${ }^{95}$

Omurtag döneminde Bulgarlar, Slav unsurun devlet yönetimine geçebileceği endişesi ve Hıristiyanlığın yayılışı ile ilgili bir takım kaygılar içerisine girmişlerdi. Nitekim Krum Han'ın Doğu Roma ile yaptığı savaşların kaçınılmaz sonucu Hıristiyanlığın Bulgaristan'da yayılışı, Trakya'dan sürgün edilerek Bulgar topraklarına yerleştirilen esirlerin kısa sürede komşu oldukları Bulgarlar ve Slavlar arasında dinlerini yaymaları, diğer yandan Slavların sayısının devlet içerisinde çok sayıda artması ve bunların devlet yönetiminin üst kademelerinde yer almaları, devlet politikalarında etkili olmaya başlamaları anlamına gelmekteydi. Diğer yandan Pagan inancının reddi Bulgarlar için Doğu Roma egemenliğinin habercisi olarak görünüyordu. ${ }^{96}$ Omurtag Han'ın ölümünden sonra yerine küçük oğlu Malamir(831-836) geçmiştir. Malamir babası gibi dışarıda barışçı, içeride Hıristiyanlık karşıtı politikaları devam ettirmiştir. ${ }^{97}$ Malamir'den sonra yerine büyük kardeşinin oğlu Presyan(836-852) geçmiştir. Presyan ile Bulgar Devleti'nin Hıristiyanlık öncesi dönemi kapanmıştır çünkü onun oğlu Knez Boris Hıristiyanlığ $\mathrm{Lkabul} \mathrm{etmiştir.}^{98}$

\section{Sonuç}

Kavimler Göçü'nün başlamasıyla birlikte Doğu Avrupa'ya çeşitli Türk kavimleri akın etmeye başlamıştır. Bu kavimlerin önlerindeki diğer kavimleri batıya doğru itmesiyle birlikte Got kavimleri tarafından sıkıştırılan Roma İmparatorluğu önce ikiye ayrılmış bir müddet sonra da İmparatorluğun Batı yarısı yıkılmıştır. Doğu Roma İmparatorluğu ise izlediği bir takım askeri ve siyasi diplomatik manevralar sayesinde ayakta durmayı başarmıştır. Doğu Roma toprakları içerisinde yer alan Doğu Avrupa, Anadolu ve Kafkaslar stratejik açıdan en eski çağlardan itibaren hep önemini korumuştur. Bu nedenle Doğu Roma toprakları her zaman saldırılara maruz kalmış ve birçok kavim İstanbul'u alarak doğu batı dünyasına egemen olmak istemiştir.

Dünya'ya egemen olma düşüncesinin yer ettiği kavimlerden biri de Bulgar Türkleri olmuştur. Dolayısıyla Doğu Avrupa'ya geldikten sonra bu hedeflerini gerçekleştirmek için sürekli Doğu Roma İmparatorluğu topraklarına saldırmışlardır. Doğu Roma İmparatorluğu ise bu saldırılardan en az zararla kurtulmak için bazı stratejilere başvurmuştur. Bu stratejilere göre ilk olarak iç karışıklık çıkararak kendisine saldıran devleti içeriden çökertmeye çalışmıştır. Bunun mümkün olmadığı zamanlarda ise düşmanımın düşmanı dostumdur ilkesinden hareketle başka devletlere savaş açmıştır. Diğer yandan ise düşmanlarına gücü yetmediği zamanlarda sadece mecbur kalınca savaşmıştır. Bu dönemlerde daha çok vergi vererek bazen toprak bağışlayarak tehlikeyi bertaraf etmeyi tercih etmiştir. Doğu Roma İmparatorluğu daha önce

\footnotetext{
${ }^{94}$ Kayapınar, agm, s.634;Feher, age, s.53; Çapan, agt, s.179-180.

${ }^{95}$ Ostrogorsky, age, s.192;Çapan, agt, s.180.

${ }^{96}$ Kayapinar, agm, s.634.

${ }^{97}$ Kurat, agm, 797; Kayapınar, agm, s.635; Feher, age, s.54.

${ }^{97}$ Kayapınar, agm, s.635.

${ }^{98}$ Vasiliev, age, s.326; Çapan, agt, s.182-183;Acaroğlu, “Bulgar Türkleri Üzerine...”, s.33;Vasiliev, age, s.353.
} 
Doğu Roma İmparatorluğu ile Bulgarlar Arasındaki Siyasi İlişkiler

diğer düşman kavimlere de uyguladığı bu stratejileri Bulgarlara da uygulamıştır. Nitekim bu stratejiler ile yaklaşık 300 yıl kadar Bulgarlar karşısında direnmeyi başarmıştır.

Bulgarlar ise Doğu Avrupa'ya çok fazla nüfus yoğunluğu ile gelmedikleri için bir müddet sonra sınırları içindeki Slav unsurlarla kaynaşmaya başlamışlardır. Bu durum bilhassa Omurtag Han döneminin son yıllarında artmıştır. Dolayısıyla bölgenin jeopolitik ve etnik yapısı Bulgarların bu duruma daha fazla direnmesini güçleştirmiştir. Ayrıca Bulgarlar arasında Hıristiyanlığın yayılma eğilimi göstermesiyle birlikte Bulgarlar IX. yüzyılın ortalarından itibaren asimile olmaya başlamışlardır. Doğu Roma İmparatorluğu ise her firsattan faydalanıp ayakta kalmayı başardığı gibi bu durumdan da faydalanmayı bilmiş ve politikalarını Bulgarlar aleyhine biçimlendirmeyi başarmıştır. Nitekim bundan sonraki dönemlerde Bulgar Türkleri Slav unsurun nüfus olarak yoğun olması nedeniyle günden güne Slav-Hıristiyan kültür içerisinde erimiştir. Kuruluşundan farklı olarak Hıristiyan-Slav kültürünün etkin olduğu bir Bulgar Devleti tarih akışı içinde rol almaya başlamıştır.

\section{Kaynakça}

\section{Kronik Eserler}

NIKEPHOROS PATRIARCH OF CONSTANTINOPLE, Shorty History, (Trans, Cyr1 MANGO), Dumbarton Oaks Research Library and Collection, Washington 1990.

THEOPHANES, The Chronicle Of Theophanes (A.D. 602-813), (Edited and Translated by Harry TURTLEDOVE), University of Pennsylvania Press, Philadelphia, 1982.

\section{Tetkik Eserler}

ACAROĞLU, M. Türker, Bulgaristan Türkleri Üzerine Araştırmalar I, IQ Kültür Sanat Yay., İstanbul -2007.

AHMETBEYOĞLU Ali, Grek Seyyahı Priskos(V.Asır)'a Göre Avrupa Hunları, Türk Dünyası Araştırmaları Vakfi, İstanbul-1995.

AHMETBEYOĞLU, Ali, Avrupa Hun İmparatorluğu, TTK Yay., Ankara-2001.

ARTAMANOV,M.İ., Hazar Tarihi(Türkler, Yahudiler,Ruslar),Çev: Ahsen BATUR, Selenge Yay., İstanbul-2004.

ÇAPAN Fatma Çapan, Balkanlar'da Bizans-Türk Illişkileri(IV.-X. Yüzyıllar), Yayınlanmamış Doktora Tezi, Elazı ̆̆ 2013.

EBERHARD, W., Çinin Şimal Komşuları, Ankara 1942.

FEHER, Geza, Bulgar Türkleri Tarihi, Ankara 1985.

GEORGE, Ostrogorsky, Bizans Devleti Tarihi, Çev: Fikret Iş1ttan, TTK Yay., Ankara-1999.

GOLDEN, P.B, Türk Halkları Tarihine Giriş, Çev: Osman KARATAY, KaraM Yay. Çorum2006.

KAFESOĞLU, İbrahim, Türk Milli Kültürü, Boğaziçi Yay., 10. Baskı, İstanbul-1993.

MORAVCSIK, Gyula,Byzantınoturcica, I-II, Budapeşte-1942.

ORKUN, Hüseyin Namık, Attila ve Oğulları, Remzi Kitaphanesi Yay., İstanbul-1933.

RASONYI LASZLO, Tuna Köprüleri, Türk Kültürünü Araştırma Enstitüsü Yay., Ankara1984. 
TEKIN Talat, Tuna Bulgarları ve Dilleri, Ankara-1987.

TODOROV, Nikolay, Bulgaristan Tarihi, Çev:Veysel Ataman, Öncü Kitapevi Yay., İstanbul1979.

VASİLIEV, A. Bizans Imparatorluğu Tarihi,Çev: A.M.MANSEL, Alfa Yay., İstanbul, 2016.

\section{Makaleler}

AHMETBEYOĞLU, Ali, “Tervel Han(702-718)”, Prof.Dr. Bekir Kütükoğlu’na Armağan, İstanbul-1991.

AHMETBEYOĞLU, Ali, Bulgar Hakanlar Listesi, Tarih Enstitüsü Dergisi, İstanbul Üniversitesi Edebiyat Fakültesi Dergisi(Ayrı Basım), İstanbul 1994.

AHMETBEYOĞLU, Ali, Kubrat Han ve Büyük Bulgar Devleti'nin Kuruluşu, Karadeniz Araştırmaları Dergisi, S.13(Bahar 2007).

AHMETBEYOĞLU,Ali, "Yurt Tutan Hükümdar Asparuh ve Tuna Bulgar Devleti'nin Kuruluşu", Omeljan Pritsak Armağanı, (Yay. Haz. M. Alpargu, Y. Öztürk), Sakarya2007.

BAŞTAV, Şerif, Sabir Türkleri, Belleten, S.17-18,1941.

BAŞTAV, Şerif, "Hazar Kağanlığı Tarihi”, Makaleler 1, Berikan Yay., Ankara-2005.

GÜÇLÜAY Sezgin, "Bulgar Hanları Krum ve Omurtag Dönemlerinde Bizans İmparatorluğu'nun Balkan Politikası", Tarih ve Siyaset Bilimi Araştırmaları, Akademisyen Kitapevi Yay., Ankara,2019.

KAFESOĞLU, İbrahim, XII. Asra Kadar İstanbul'un Türkler Tarafindan Muhasaralar, İstanbul Enstitüsü Dergisi, C.III., İstanbul-1957.

KAFESOĞLU, İbrahim, Türk-Bulgar'ların Tarih ve Kültürüne Kısa Bir Bakış, Güney Doğu Avrupa Araştırmaları Dergisi, S.10-11, İstanbul Üniversitesi Edebiyat Fak. Basımevi, İstanbul 1983.

KAFESOĞLU, İbrahim, "Bulgarların Kökeni”, Türk Kültürünü Araştırma Enstitüsü, Ankara1985.

KARATAY, Osman, “Omurtak Han'ın Rüyası”, Türk Dünyası Tarih Dergisi, S.183, Mart 2002.

KARATAY,Osman, Tuna Bulgar Devletinin İlk Asrı:Balkanlarda Tutunma ve Pekişme(681803), Türk Dünyası İncelemeleri Dergisi, S.X/2,Kış 2010.

KAYAPINAR Ayşe, Tuna Bulgar Devleti(679-1018), Türkler Ansiklopedisi, C.II, Yeni Türkiye Yay., Ankara-2002.

KURAT, Akdes Nimet, "Bulgar", İslam Ansiklopedisi, C.II, Milli Eğitim Basımevi Yay., İstanbul, 1961.

MíFTAKOV, Z., “illk Bulgar Devlet Oluşumları”, Türkler Ansiklopedisi, C.II, Yeni Türkiye Yay., Ankara-2002. 
Doğu Roma İmparatorluğu ile Bulgarlar Arasındaki Siyasi İlişkiler

ÖZLÜ Zeynel- TİRYAKİ Kerim, “Tarihi Süreçte Karadeniz'in Jeopolitik Önemi(BULGAR SAVA N.IVANOF'A GÖRE)",Illkçağlardan Günümüze Jeostratejik ve Jeopolitik Açıdan KARADENiZ, Akçağ Yayınları, Ankara 2018.

ZLATARSKİ, V.N, "Krum Han”, Güney Doğu Avrupa Araştırmaları Dergisi, Çev: M.Türker Acaroğlu, S.10-11, İstanbul 1983. 